\title{
The West and the Middle East: Liberal Nationalism, Instrumental Nationalism
}

\author{
Gadi Hitman \\ Ariel University and Beitberl Academic College, Israel
}

\begin{abstract}
This paper argues that there is no real nationalism in the Middle East and if is, then it is an instrumental. The historical process of the region which relates to nationalism has had three stages: (1) the European conquest that forced the indigenous people to battle both for freedom and confront a secular idea such as nationalism; (2) arbitrarily marked borders by the West disregarding ethnic religious and tribal lines and affinity; (3) the creation of Arab nation states with no solid infrastructure of shared national values. This perspective can help understand current political developments in light of the Arab spring upheavals, in Iraq, Syria and Libya.
\end{abstract}

Keywords: Arab spring, liberalism, nationalism, instrumental-ism, tribalism

\section{Introduction}

Some prominent scholars argue over explanations for the emergence of nationalism. Whether one believes the idea has a primordial basis, as Smith (2000) maintains, or adopts the instrumental approach of Gellner (1983), there is a consensus that it all began in Europe. Even Anderson's definition (2006) that a nation is an imagined political community does not clash with the argument that Europe is the continent of nationalism. It was Kohn who argued that "nationalism is the process of integration of the masses of the people into a common political form” (Kohn, 1946, p. 4). Still, there is a significant difference between the crystallization of the nation state in Europe and the Middle East.

This paper suggests a new perspective on the nationalism emergence process in the West and in the Middle East. Based on prominent theories from political science disciplines, the paper analyzes the historical process in the two regions. The first section will discuss Europe, where nationalism started as an abstract idea, meaning a constructivist process that turns into a tangible action of separation between Church institutions and state mechanisms (secularization). The third stage was the establishment of nationalism on the basis of the French Revolution's liberal values, be it primordial, instrumental or imagined.

The following scheme can demonstrate the evolvement stages of nationalism in the West.

Stage 1
An abstract idea

Stage 2
Separation of church and state

Stage 3

Liberal nation states

\section{Nationalism in the West}

What is nationality? Greenfeld identifies nine stages in the development of the term "nation”, originally

Gadi Hitman, Ph.D., adjunct Professor, Political Science and Middle East Studies, Ariel University.

Correspondence concerning this article should be addressed to 8 Brener Street, Kfar Sava, Israel, Zip Code 4434908. 
derived from the Latin word "nation" meaning "something is born"1. The term had acquired new meanings throughout history: At first, it described foreigners in ancient Rome, and then reflected student life in the Middle Ages. At the beginning of the 16th century, England was the first place where the term referred not only to specific groups, but to the population at large. Even if no one argues that Reformation and Renaissance can be called the age of nationalism, those years were the first in the history of mankind in which the individual was regarded by some philosophers from a new perspective. It is referred to by political scientists as the constructivist approach, where by social factors, namely people, create the social and political order.

The first stage in Europe began during the Enlightenment era, when people started to wonder about the nature of society. People like Machiavelli in Florence, Thomas More in England and René Descartes in France introduced values such as liberalism to the world by interpreting classic texts and Holy Scriptures in a new way $^{2}$. Historically speaking, it was these pioneers who shifted human thought from the theological to the anthropological and rational philosophical-leading the way to the implementation of a community-based society, in which monarchs no longer determined their subjects' daily life and future in their capacity as God's representatives on Earth, but rather the communities, that would later turn into nations.

However, it took two more centuries before the idea turned into reality. The Treaty of West Phalia signed in 1648 was a historical cornerstone in the establishment of what would later become a sovereign state, but only during the French Revolution, in 1789, would nationalism become substantial and bring about ethical change. Until then, the national states of Western Europe regarded themselves as one Christian polity. Even the address of Henry Francois d'Aguesseau in 1715 did not make the practical change. It took 74 more years before his words turned into a reality: "Only in the republics did citizens grow up to identify the interest and fortunes of the state with their own"3.

The revolution of 1789 led to the implementation of values such as liberty, equality and fraternity, which became the basic pillar for people in the West. It was not only the feeling of belonging to the patria (father land) as people perceived; it was also the completion of the institutionalization process which included a separation of powers between the government (the executive), parliament (the legislative) and court system (the judicial). The next step was a long struggle of the people, the new nation in its modern meaning, to achieve independent states based on liberal values.

The new liberal nation states were created at the same time as Church supervision over matters of the state and the people's daily life was lessened, and in 1636 Roger Williams founded Providence as the first community to completely separate between church and state ${ }^{4}$. This dramatic change contained a new perspective, placing the individual at the center. As Greenfeld describes it: "Nationalism is a fundamentally secular and humanistic consciousness based on the principles of popular sovereignty and egalitarianism. These three characteristics are present in every specific case of nationalism” ${ }^{25}$. Contrary to the process in the West, this kind of development did not occur in the Middle East, where some Arab leaders manipulated the people by making the occasional use of Islam as an instrument for their national (or own) interest.

Although a distinction may theoretically be made between the establishment of Germany, France, or Italy

\footnotetext{
1 Tamir, 1995, p. 427.

2 Kohn, 1946, pp. 120-121.

3 Kohn, 1946, p. 205.

4 Kohn, 1946, p. 191.

${ }^{5}$ Greenfeld, 2004, p. 4.
} 
(each under its unique conditions), this, in simple terms, is the story of the creation of liberal nationalism in Europe $^{6}$ - an abstract idea that turns into a tangible state established on the basis of enlightened principles. It is therefore not surprising that this process is not undisputed among scholars, whether their approach is instrumental, primordial or imaginary when trying to unravel the nationalism enigma.

This liberal thought has existed in the West for more than two hundred years. The individual, both in liberal and republican democracies, remains at the center. The religious institution is separate from state affairs, and no king, president or prime minister is considered to be a representative of God. However, none of the above had any negative impact on national feelings, as can be seen, for instance, during sports competitions. Maybe the most solid evidence that liberal nationalism exists is not the structure of the political system in the western states, but the fact that more than 20 new states have been established since 1990 in Europe, all of which strive to imitate the western components such as democracy, human rights and liberalism.

\section{Nationalism in the Middle East}

Nationalism in the Middle East has evolved differently historically. The idea of nationalism penetrated in the 19th century by European conquering. The first stage therefore was a struggle against foreigners, not only in order to remove them out of the region, but by way of objecting to their new thought, which contradicted the basic principle of Islam, i.e. that the nation (umma) has no physical borders ${ }^{7}$. The second stage was to arbitrarily marked borders by the West. This was done according to British or French interests that disregarded ethnic, religious or tribal elements of the local population whether in Egypt, Sudan, Iraq, Syria or elsewhere. This process has led to a third stage which was the creation of Arab nation states without a solid nationalist infrastructure. This development has a crucial influence to these days, especially in heterogeneous societies such as Syria, Libya or Iraq. Some Arab leaders used this situation to base instrumental nationalism almost everywhere as will be demonstrated below by the cases of Syria, Iraq and Libya.

The following chart demonstrates the stages of the evolution of nationalism in the Middle East:

\begin{tabular}{|c|c|c|}
\hline $\begin{array}{c}\text { Stage } 1 \\
\text { European conquest }\end{array}$ & $\begin{array}{c}\text { Stage } 2 \\
\text { Stage } 3 \\
\text { Arab nation states }\end{array}$ \\
\hline
\end{tabular}

Arab philosophers, be they Muslim or Christian, have been influenced by western ideas, mainly those that came from France, and this influence raised questions regarding the nature of society rather than focusing on the nationalism aspect. Thus nationalism in the Middle East is completely different than in the West, and cannot be discussed before the second half of the 19th century. It took almost an entire century since Napoleon's invasion of Egypt before new theories and ideas penetrated Arab philosophy in the region.

Until the late 19th century, the Ottoman Sultan, who controlled the region, was perceived in the Muslim world as God's emissary, the protector of the Holy places and the defender of frontiers against Christianity. None of his subjects, except for the Zionist movement, raised the possibility of unique nationalism for a specific territory under his authority. Moreover, it had never occurred to the Sultans to divide the Empire on the basis of ethnicity and potentially pave the way for nation states. However, the Empire did not seek to merge the

\footnotetext{
${ }^{6}$ Differences may relate to the definitions of ethnic nationalism (Germany), territorial nationality (France) or imagined nationality whereby one perceives language as a common and unifying value (Switzerland), but all three states mentioned would be categorized as liberal.

${ }^{7}$ According to the Quran, Muslims have a universal mission, not a national one. Islam sets up a single society and rejects limited tribal and national units which only think of their own interests. See: Naqavi, A. 1998, p. 50.
} 
different ethnic and religious communities under a single nation state either; when it started to decline and the Sultans were forced to make reforms, it did not turn to liberal thought. The only liberal value that was adopted from the West was the understanding that all subjects deserve full security. Hourani (1970) wondered about the moral and legal basis of the Empire since substantial elements of liberal thought, such as policies with regard to minorities or the status of women, lagged far behind the Western model.

The first attempt to establish an Islamic state, as opposed to an Islamic Caliphate, was under the Ottoman Empire during the 18th century. Two families-Al-Wahab and Al-Saud-joined forces to implement the Sharia (Islamic law) among tribes in the Arab Peninsula. This move laid the foundations for the establishment of Saudi Arabia, and it was based on a religious rather than a national vision. The first signs of new Arab thought were seen from 1850, when people like Rifaa al-Tahtawi, Jamal al-Din al-Afghani and Muhammad Abduh, were exposed to new ideas, and some even travelled to France and discovered a different society. A careful analysis of their ideology raises a key question related to this study: what is an Arab nationality and is it possible to identify a unique nationality for Arab nation states? It is true that every Arab nation state has its own national anthem and flag, but these are merely symbols. What actually lies behind them?

In his comprehensive study on Arab Thought, Albert Hourani, one of the most prominent scholars in the Middle East, tried to trace the origins of Arab nationalism. He began with the common denominator-the Arabic language - and continued with the socio-cultural dimension of nomadic tribes ${ }^{8}$. Philosophically speaking, Hourani's argument is both relevant and interesting to the discussion about Arab nationalism: If the final goal of a given group of people is a nation state, how does it fit in with a nomadic society? This is not the only problem when analyzing nationalism in the Middle East. The vast majority of people in Arab countries are Muslims, and basic Islam rejects nationalism because the tangible expression of the idea is a nation state on specific territory within limited borders, while Islam sees an Umma (community of all believers) under one regime. In Hourani’s words: “All Muslims, whatever their culture or racial origin, were equal members in the umma, the limited community, possessing the same rights and responsibility" . This was the case with Sunni Muslims—no one else, Shiites, Christians or Jews—-were entitled to have the same rights. As for the Shiites, they were regarded with suspicion not only because of their age-old animosity towards Sunna, but because of their affinity with Persia. This is a critical point for discussion on national identity in heterogeneous societies, as I will argue below.

From a chronological point of view, al-Tahtawi was the first Arab philosopher to speak of nationalism. His biography, which included five years in Paris, shaped his philosophical thinking. He was exposed to a completely different society, customs and values, and perhaps it was his witnessing the revolution of 1830 that led to the removal of King Charles $\mathrm{X}$ that had sown the seeds of a new idea in his head about the people's power and demands. In spite of what he had seen in Paris, his view of the state was not liberal, as the idea was considered to be in 19th century Europe. Although he believed that the government should be in the hands of the people, he also maintained that the ruler should have absolute executive power in accordance with Islamic law $^{10}$. He also thought that the idea of revolutionary action to seek equality and freedom is not relevant to Egypt, which was ruled by a Muslim autocrat, despite support of liberty under the belief that it alone can build a real community or society. At the same time, he called for strengthening the education system in the interest

\footnotetext{
${ }^{8}$ Hourani, 1970, p. 1.

${ }^{9}$ Hourani, 1970, p. 29.

${ }^{10}$ Hourani, 1970, p. 73.
} 
of the next generation, and instilling the love of the homeland (watania) in people's hearts, which also meant willingness to sacrifice your life for your country. This is a crucial point in the discussion because al-Tahtawi distinguishes between the Islamic nation (итma) and the love of the homeland and patriotism, meaning a specific territory. In other words, this is a tangible form of nationalism, however, far from liberal. Here al-Tahtawi refers to Egypt and not to the Arabs; to the people who lived in Egypt and not to all Arabic speakers. Modern Egypt is the descendent of something from the past, from the time of the Pharaohs. If we accept this argument, then we can claim for unique Egyptian nationalism that is not purely Islamic or Arabic, and this is a historical development that is limited to Egypt as opposed to the historical development of other nation states in the Middle East ${ }^{11}$.

Al-Tahtawi did not fully develop a unique Egyptian nationalism, least of all a liberal one, and there are several explanations why. First, he supported equal rights to women by law, but not in the political and public life, which does not amount to liberal thought. Second, although he aimed to distinguish between an all Arab community and Egyptian society based on a combination of Islam and the age of the Pharaohs, he failed to deliver this idea to the political echelon in Cairo. Third, he was ahead of his time, because he wrote in Egypt under an Islamic Empire and although the regime was Turkish and not Arab, it was still Muslim. This fact prevented a real struggle for independence on the basis of Egyptian nationalism. When it came to a struggle against the West in 1919, it was a battle between all Arabs and the West all over the Middle East.

In another part of the Middle East in the 19th century, another Arab philosopher tried to develop unique nationalism, this time in Syria. Butrus al-Bustani (1819-1883), an Arab Maronite Christian, was a true adherent of western values, starting with national unity, which he had interpreted to mean the willingness of all who share the same country to cooperate on a level of equality ${ }^{12}$. Like al-Tahtawi in Egypt, Bustani did not doubt the Sultan's authority and did not call for disengagement from the Empire. In his vision, he saw a full separation between religious and secular realms, understanding that the heterogeneous society in Syria will find it difficult to establish national unity based on common history. His thought was premature for mid-19th century Syria because of the political reality, meaning that he could not promote his ideas under the regime of the Ottoman Empire in a traditional society that basic loyalties were to family, tribe and religious communities. Even a century later, when Antoun Saadeh, a Lebanese philosopher, founded a Syrian social national party in 1932, the attempt failed. Although the party's platform stressed that "the Syrian nation is a product of the ethnic unity of the Syrian people”, the idea was perceived as a threat in Damascus and Saadeh was executed in $1949^{13}$. Saadeh's challenge on the Arabic-Islamic history, and the philosophy of secular society in Syria, was considered a nightmare in $1949^{14}$.

Al-Tahtawi and Bustani were not alone. Al-Afghani and Abduh also tried to bring new ideas to the Arab and Muslim world; however, neither preached for liberalism. Al-Afghani is considered to be "the father of modern Islam”. There is no hint in his works on Arabism as a unified term, but he did call for national unity based on Islam in order to struggle against the danger coming from the West. He did not mention unique Iraqi, Lebanese or Syrian nationalism or the likes, but he did believe that a constitution is needed to limit the ruler's power. His ideology was comprised of two major issues: a struggle against the West, meaning mainly the

\footnotetext{
11 Tahtawi-al, R. 1912, p. 206.

12 Tahtawi-al, R. 1912, pp. 100-101.

13 Kader, paragraph 4.

14 Ajami, 2009, pp. 68-71.
} 
colonialism of Great Britain and France; and, at the same time, an effort to establish pan-Islamic unity, as opposed to an Arab one ${ }^{15}$. We can argue therefore that his idea was a form of religious nationality based on Islam, which views religion and state as inseparable. He truly believed that his mission was to persuade Muslims to properly understand their religion. As I will later argue, this type of nationalism was in use in some Arab states during the second half of the twentieth century. Abduh, like his teacher, believed that the holy book of Islam and its exegesis were sealed in the mediaeval age and do not provide answers to the people's questions in modern times. He was in favor of human rights, much more than the Koran allows, but having shared his liberal line of thinking only with the Egyptian elite, had failed to bring about a similar philosophical and practical breakthrough to the one in the West.

Mohammad Abduh's philosophy is in fact identical to al-Afaghani's since he was his disciple. His main concern was fixing the problems in Egypt's society, and he was aware of the danger of dividing into two separate groups as a result of increasing secularization. Moreover, despite his admiration of the progress made by Europe, Abduh did not believe in importing laws from one society into another because he maintained that every community needs its own unique laws ${ }^{16}$. By that, Abduh rejected laws that were based on liberal thought and encouraged full equality between people as basis for a collective identity of nationalism. Abduh supported a collective judgment of the community, claiming it was not infallible and that people must remain true believers in Islam, not liberal thought, because religion is the most powerful factor in the moral system ${ }^{17}$. The ideal society is the early Islamic nation (umma), when people were considered salaf ${ }^{18}$, and if so, it can by any interpretation be liberal. The same conclusion correlates with his thinking that non-Muslims are part of the nation, but at the same time assuming that a despotic ruler is the best option if he, and only he, is able to promote society ${ }^{19}$.

To conclude, Arab philosophers based their concepts on strong and solid religious arguments. They looked for answers to Muslim society's needs, while seeking support in the expulsion of western conquerors from the Middle East. None of them suggested, for instance, separation of powers or full equality between men and women, as commonly found in liberalism ${ }^{20}$. None of them wrote about a unique nationalism, certainly not on a liberal basis, for any country which was under Islamic (albeit Turkish) rule, except in Egypt ${ }^{21}$. This raises the question of what kind of nationalism can be found in the Middle East, which becomes even more relevant when bearing in mind that the modern history of the Arab world has seen bitter inter-Arab conflicts between different states, as well as internal civil wars.

\section{Arab Nation States but Not Nationality}

If the first stage was a struggle against the West, the second stage can be called the establishment of Arab nation states under decisions taken by the West. It began shortly after the First World War ended. The

\footnotetext{
${ }^{15}$ Hourani, 1970, pp. 109, 115. Al-Afghani was a strict adherent of basic roots of Islam, and refused to accept any idea or thought relating to Islam that tried to suggest another explanation coming from modern Muslim movements.

${ }_{16}$ Hourani, 1970, p. 136. See also: Rida 1931, pp. 103, 157.

17 Abduh, 1942-1943, p. 145.

18 A movement within Islam named after the term salaf, meaning "predecessors” or "ancestors", and used to identify the earliest Muslims.

19 Rida, 1931, p. 361.

20 Amin Qasem, one of Abduh's students, wrote a book in 1899 which demanded the emancipation of women which was received with hostility and bad publicity. See: Qasem, 1899, p. 116.

${ }^{21}$ Egyptians are bound together by the shared history of living in the same territory before Islam was revealed to the Prophet. I am not ignoring the texts of Abd Allah Nadin, for instance, which called for Egyptian nationalism, but he was a single voice and during his time, the late nineteenth century, it was too early for Egypt's society to adopt it.
} 
Sykes-Picot agreement in 1916 and the implementation of the Versailles Treaty marked the international acceptance of France and Great Britain's control in the Middle East. Every Middle East student learns that Egypt's borders were drawn by Great Britain and France, or that Jordan and Iraq were divided by the British mandate between Faisal and Abdallah. France itself decided on the "Great Lebanon" plan under Maronite authority (not a Lebanese one-a point that again raises the question what is nationality in a heterogeneous society such as Lebanon's). In Ajami’s words “The Maronite community had a strong self-identity, separate from the Arab-Muslim world”22. Ajami, a great scholar in his own right and a Shiite from Lebanon, describes, that he could not feel part of Maronite history. If this description is true, is it possible to talk of a Lebanese national identity, when the largest group of citizens (at the beginning of the 20th century) is excluded?

The subsequent period saw further attempts to fragment the Arab world and set up separate states in each piece. These states were based on the Western Orientalist "mosaic" perceptions, whereby certain subgroups in Arab society were defined as "national" constituents, but the foundations were far from solid. For example, states were proposed for the Alawites and Druze in Syria, Berbers in North Africa, and Kurds in Iraq. Parts of one country were annexed to another (for example, Iskenderun to Turkey); where as some communities were imposed on others within the same country (for example, the Maronites in Lebanon) ${ }^{23}$.

This policy of the western powers was a direct continuation of the British control in Egypt since 1879. It contributed greatly to the emergence of resistance against foreigners, and was politically expressed by the establishment of new movements and parties. In Egypt, these were the national party in 1907, followed by the wafd in 1919, and later the Muslim Brotherhood in 1928. In Syria, these were the communist party in 1924 and the Syria Social National Party (SSNP) in 1932. These organizations were too weak, and their activity too focused against foreigners and political rivals. All of them, perhaps with the exception of the SSNP, forgot the essence, namely creating a collective national identity, although they hoped to achieve it. George Antonius wrote that "There is so much factionalism over national matters and the disagreements between the parties are so bitter, that no one accepts a certain idea unless it serves their narrow interest”24. Freya Stark, a British traveler, visited Syria in 1928 and wrote: "I haven't yet come across one spark of nationalist feeling. It is all sects, hatred and religions”,25. Historically, the western superpowers decided when to end their mandate in the Middle East, and when they did, the third stage was the creation of independent Arab nation states.

An immediate outcome of this historical development was unstable political systems in the new independent states. True, not all of them had experienced the same extent of violence, but the "golden square" comprised of Syria, Iraq, Lebanon and Egypt did witness civil wars or military coups. This did not leave much time to cultivate solid nationalism in these states. They, much like the entire region, are still undergoing the continuous swing from Islam to modernization, from a religious moral society to an advanced one, and are running the risk of exploding over secularization. And through it all, the same questions remain: "who are we?”; "what is our identity?"; and "what might bring true unity to the Arab world”. Despite countless attempts to change the socio-traditional order, the family is still the basic unit of the social organization and production in traditional and contemporary Arab society ${ }^{26}$. If that is the case, then loyalty lies with the head of the family. If

\footnotetext{
22 Ajami, 2009, p. 26.

23 Barakat, 1993, p. 6.

${ }^{24}$ Quoted in Ajami, 2009, p. 31.

25 Pipes, 1993, p. 13.

26 Barakat, 1993, p .23.
} 
two or more families cannot agree on the same values, how is it possible to base a wide collective identity? This argument is valid for Arab society across the Middle East since it is heterogeneous; although there are certain elements of unity (language, common culture, geography, or shared history), there are also elements of fragmentation (tribalism, ethnic solidarity, localism, or regionalism). At present it seems the latter vanquish the former.

This socio-political reality craved an Arab leader who could make adjustments in order to survive both physically and politically, including ongoing efforts to create a national collective identity, not without success. This nationalism, based on instrumentalism, will be demonstrated below through the case studies of Iraq Syria, and Libya ${ }^{27}$.

\section{Iraq}

If anyone were to argue that Iraq has seen some political stability, it was only under Saddam Hussein's regime. From the day it was established in 1932 to the Ba'ath revolution in 1968, this country had witnessed countless political upheavals, first as a monarchy and later as a republic. After 1968, the Ba'ath regime tried to implement a policy of secularization. It was not only the party's platform. It was also an attempt to blur out the public religious identity due to the traditional conflicts between Sunnis and Shiites ${ }^{28}$. Politically, Saddam strived to eradicate any religious tension, not only in his own party but all over the state. He understood that the Shiite majority can easily stab him in the back. In 1977, he stated: "Some of the reactionary forces have started to use the religious for political needs...No one allows doing so because we are against the politicization of the religious faith. We will stand up against it”29. He explained his conception by arguing that the adaptation of religious policy will likely cause rifts in Iraqi society and perhaps more importantly, shock the ideological structure of the Ba'ath party.

Saddam's ideology was to inculcate secularnationalism in Iraq, but in practice, he was using different policies against Shiites and Sunnis: While the orthodox Sunni population, to which he belonged, was allowed to hold its religious ceremonies, Shiites were restricted from doing the same. Since Saddam was concerned about the implications of the revolution in Iran on the Shiite majority in Iraq, including the potential fostering of Shia-based religious nationalism, he executed several Shiite clergymen.

A series of events in the late 1970s and early 1980s caused Saddam to change direction and use Islam for political needs, including boosting nationalism. In the internal arena, Saddam completed his control of the state in 1979. He wanted the Shiites to accept him as the president and therefore began to visit Shiite mosques. In the external sphere, a war had broken out between Iraq and Iran in 1980. Saddam soon realized that Iranian soldiers are motivated by religion, whereas the Ba'ath platform did not encourage Iraqi soldiers, most of whom were Shiite, to sacrifice themselves for their nation. In order to change this state of affairs, Saddam began to send clergymen to the front and gave Islamic names to army units. A decade later, facing a military coalition in response to Iraq's incursion of Kuwait, Saddam added the slogan "God is great” (Allah u-Akbar) to the Iraqi

\footnotetext{
27 These two countries were selected as case studies because Damascus and Baghdad (along with Beirut and Cairo) are considered to be the birthplaces of Arab philosophy. Another reason is that nationalism in the Gulf States relies primarily on tribes who are too religious and traditional to accept new ideas. Lebanon is a unique case since, according to its constitution, the elected president must be a Maronite. This condition automatically creates inequality between its citizens and therefore there is no liberalism in the Lebanese political system.

${ }_{28}$ Bengio, 2012, p. 11.

29 Hussein, 1979, pp. 26, 32.
} 
flag, hoping that an Islamic symbol would help to mend the cracks in his coalition ${ }^{30}$. His public statements during those years contained religious symbols. After the war, in 1988, Saddam led a religious campaign that aimed to encourage Qura'an study. He even promised Iraqi prisoners to be lenient with their sentencing if they learn well. Bengio claims that Saddam's return to Islam was authentic ${ }^{31}$. Accepting this argument leads to the conclusion that Saddam needed the religious retreat to survive politically and physically, because there was no real basis, certainly not Iraqi nationalism, that bound the heterogeneous population of Iraq together after having suffered such brutal repression under his regime. And if we stick to Bangio's argument, this turnaround of Saddam not only puts in question his secular policy based on Ba'ath principles, but proves that he used the religion as an instrument to crystallize Iraqi nationalism. Taking the discussion one step further, the Shiite upheaval after 2003 and the entrance of global Jihad groups into Iraq in the last decade, as well as the results of the 2005 elections, in which most voters voted on a sectarian basis, are solid evidence in support of the argument that Iraq is still searching for its self-identity. Saddam's attempts to find it, with his instrumental approach by using both Islam and the Ba'ath platform, have ended in failure.

\section{Syria}

Syria, like Iraq, had suffered from political instability from its establishment in 1946 until at least the mid-1960s. Nine presidents and 27 prime ministers came and went by 1963, and this astounding figure tells the political story ${ }^{32}$. Each of the Syrian leaders was too busy to stabilize his regime and all of them failed.

After 1963, the Ba'ath party became the strongest political power in Syria and, according to the party's platform, the state was defined as secular. The Syrian Minister of Religious Affairs made it clear by stating that "Syria is a secular state but that does not mean that it is against religion, even if Islam is no basis for a political plan”33. The political heritage and demographic composition of the population (40\% minorities; a mix of Alawites, Kurds, Sunnis, Shiites, Druze and Christians) make instrumental nationalism clearer than in Iraq. The simple fact that the rulers belonged to a minority group (as in Iraq, but not to the orthodox Sunni Islam) has contributed to this tendency.

The dominant approach in the early years of the Ba'ath regime was to move away from Islam and base the state on secular nationalism, according to the socialist concept of unity and freedom ${ }^{34}$. The neo-Ba'ath group strived to erase the Islamic basis from Syrian nationalism mainly because it was aware of its problematic situation as a ruling minority ${ }^{35}$. Religious education and preaching were banned outside mosques, and clergymen who opposed the regime were executed. ${ }^{36}$

This extreme policy could not build a Syrian national identity due to the Sunni majority's opposition. The Muslim Brotherhood tried to protest and pressure the regime into taking Islam into consideration. What Abduh and others wrote a century ago became reality in Syria. After 1970, President Assad, again in order to strengthen his political power, tried to build a different basis for Syrian nationality. He became close to Islam and inter alia made pilgrimage to Mecca, prayed in Sunni mosques in Damascus and even integrated

\footnotetext{
${ }^{30}$ Al-Qaddisiyya, 1990.

31 Bengio, 2012, p. 15.

32 Sela, 2013.

33 In an interview to BBC Radio in Arabic, 7 September, 2009.

34 The Ba'ath founders were a mix of Muslims, Christians and Druze.

35 Maoz, 1974, pp. 85-86.

36 Rabinovich, 1972, pp. 109-116.
} 
clergymen into his regime system ${ }^{37}$. This did not help to unify the people. In 1973, when Assad sought to approve Syria's new constitution without including in it a specific article saying that the president must be Muslim, the country was shaken by protests and violence. This led to an Islamic uprising that lasted for six years. The two sides, Assad and the Muslim Brotherhood, struggled to recruit as many supporters as they could. The final target was not only survival; it was a battle over Syria's identity. This was solid evidence that no real basis binds the heterogeneous population together and that ethnic affinity is dominant in Syrian's society.

This mutiny, which ended in 1982 with Assad's victory and a crushing blow to the Muslim Brotherhood in Syria, did not stop the Syrian president from introducing himself as the guard of Islam. Again, the goal was to survive—politically and physically—and for that end, all means were justified. One of the prominent steps that Assad took was to help Muslim movements, such as Hamas. By that he attained religious, but not national, legitimization of his regime ${ }^{38}$. But the ongoing crisis, even without clashes, between the secular policy introduced by Assad's family and political Islam, makes it difficult, if not impossible, to establish solidarity and national unity. Bashar Assad, knowing that Syrian society is of a religious nature ${ }^{39}$, changed his policy and adopted a new approach: turning Syria into an Islamic, but not a religious, state. This policy includes an effort to Islamize the Alawite minority (to which Assad belongs), permission to pray inside the army and building new centers for teaching Quran. In addition, Bashar continued the policy of his father by bringing close to him Sunni high ranking army officers and to promise their loyalty to his regime.

The ongoing civil war in Syria, which began in March 2011, proves that the Syrian regime's instrumental line of thinking has failed. There is no common denominator among Syrians, who are still split into Muslims and non-Muslims, or within the Muslim world. It seems that calling for stepping down of the old regime is not enough. Something else is needed in order to determine if we can create an authentic Syrian nationalism that may contribute to keep us together.

The entrance of global jihad organizations alongside the activity of ISIS raises the question: "what is Syria today"? Can we really say that the nation state recognized by the international community still exists in its formal territory? Is Syria undergoing a process of disintegration? And if these are the questions, how can someone argue in favor of Syrian nationalism?

\section{Libya}

The North African territory that currently composes the nation state of Libya has a long cultural history as a center of Phoenician, Carthaginian, Roman, Berber and Arab civilizations ${ }^{40}$. Not surprisingly, none of the above has ever helped the Libyan people to base a unique nationalism and these political entities do no longer exist. The population in Libya, much like in Syria and Iraq, is heterogeneous, a mix of Arab and Barbarian tribes. Islam became the basis for social life, and the Sanussiorder ${ }^{41}$ grew dominant in the 19th century. Like Egypt and Syria, Libya was also under the Ottoman Empire's rule at the beginning of the 20th century. This historical development, together with the absence of intellectuals, did not provide the conditions for thinking

\footnotetext{
37 Zisser, 2003, pp. 245-249.

38 Al-Quds al-Arabi, 1998.

39 The Ministry of religious affairs estimated in 2005 that at least 7 million Syrians go to mosques every Friday. See: al-Hayat, May 3, 2005.

40 Blanchrad \& Zanotti, 2011, pp. 3-4.

${ }^{41}$ This Islamic movement calls for socio-political order according to Islamic law (Shari'a), unification of all Islamic sects, Jihad against foreigners, and dissemination of Islam.
} 
about nationalism, as it contradicts Islam.

After the Italian occupation in 1912, the Sanussi resistance fighters and Cyrenaica region (Eastern Libya) attempted to expel the foreigners, but failed. It took more than 25 years for Italy to agree to withdraw its forces from Libya, and like other case studies, the Libyan territory was divided between Britain and France in 1947. Four years later, Libya became an independent state. During his reign from 1951 to 1969, King Idris I tried to unify the new state through a constitution that entered into force in 1949 and the establishment of a national Congress. These steps did not suffice to develop Libyan identity for people from different roots, tribes and counties. The traditional political center in Tripoli was weak, the tribal center in Cyrenaica was destroyed and in Fezzan, the southern part of the new state, there were no signs of any political activity. King Idris I was therefore forced to maneuver between the various interests of different groups, tribes and regions ${ }^{42}$. At the same time, he surrounded himself with people from his own origin and promised to reward them for their loyalty.

King Idris I did not promote the establishment of Libyan nationalism, and yet at least once he used his position to reinforce himself as a national symbol. After the student demonstrations in 1964, he resigned, but later withdrew his resignation at the people's request ${ }^{43}$. He also agreed to establish national institutions, which had no real political power, and used them as a tool to develop Libyan nationalism, which unfortunately was a failure foretold. Provincial ties continued to be more important than national ones, and the federal and provincial governments were constantly in dispute over their respective spheres of authority. King Idris I was first and foremost from Cyrenaica in east Libya, and thus never at ease in Tripoli. His political interests were essentially Cyrenaican, and he understood that whatever real power he had lay in the loyalty he commanded as Amir of Cyrenaica and head of the Sanussiorder ${ }^{44}$.

Moammar Qadhafi's era stretched from September 1969 to October 2011. He saw the national struggle as a basis for history, and nationalism as a basis for nations ${ }^{45}$. This, of course, is a mirror image of the process in Europe, which started as a theoretical thought and became a tangible form. But even if we accept Qadhafi's conception, what kind of nationalism can we identify? My point here is simple: by analyzing his ideology and his 42 years as a dictator, we can argue, at most, for Arab nationalism (which is nothing but a vision), and say that Qadhafi was one of its many adherents. In times of political crisis and instability, Qadhafi went back to basics, to family, which every Libyan is familiar with, using instrumentalism to keep his regime stable and protect his relatives. His basic perspective regarding nationalism was a primordial one. He believed that an individual cares about his/her family more than about the tribe or state, and therefore describes a development process of loyalty and identity which starts with the family, continues with the tribe and ends in the nation state. In his vision, he saw Islam taking control over Europe again, an abstract idea that contradicts nationalism ${ }^{46}$. The major lacuna with his primordial approach is that the essence of the nationality's sense of belonging is missing.

But his deeds did not help to build true Libyan nationalism. On the radio, on the very day of the revolution, he announced the establishment of an Arab Libyan Republic, a name which illustrated his all-Arab view. Two weeks later (September 16, 1969), he stated that the enemies of the revolution were two-fold: imperialism and Zionism, and the people were warned that the struggle against them was just beginning. The slogans freedom,

\footnotetext{
42 Gera 1983, p. 29.

43 Ibid., p. 32.

44 Chapin Metz, 1988.

45 Qadhafi 1975, p. 22.

46 Silver, D. 2011.
} 
socialism, and unity were used as reference points to capsulize the direction that domestic and foreign policy would take. This was the first instrumental attempt to call for Libyan national unification in order to fight against the enemies ${ }^{47}$. Following this step, he did not renew the agreements with the British and US administrations, and both states evacuated their people from army bases in Libya in 1970. The two dates became national holidays, a symbol for victory over the $\mathrm{West}^{48}$.

Nationalistic actions in the economic sphere began with Qadhafi's decision to demand that foreign banks form Libyan joint stock companies with at least $51 \%$ of their shares owned by the government. In December 1971, the Libyan government nationalized all of the British Petroleum Company's assets. By 1 September 1973, nationalization had become widespread, including $51 \%$ of the assets of all oil companies operating in Libya. The only appropriate and acceptable role for Libyans was to support the revolution and promote the accomplishment of its goals. In this sense, growing domestic repression and control belied the regime's alleged concern for the liberation of the individual. All these steps helped Qadhafi form instrumental nationalism for the Libyan people by using political decisions and political institutions for creating Libyan nationalism. But under the surface there was nothing real to bind the people together. Naturally, this policy did not contribute to authentic Libyan nationalism, but to Qadhafi's personal interests. Newly discovered documents prove that the Libyan ruler and his family were deeply involved in acts of corruption that helped them become extremely rich and survive politically ${ }^{49}$. It was not only the money. It was pure nepotism to ensure stability and dominance of the family without taking the people's needs into consideration. However, in times of crisis, Qadhafi came back to the basic primordial aspects of being a loyal Libyan, calling upon his people to join forces and beat the evil ones. When the Arab spring turmoil started all over Libya, Qadhafi promised that millions will march to pure Libya, calling the Libyan people to go out to the streets, but it was too little too late ${ }^{50}$. As an authoritarian leader that regarded himself as an all-Arab leader, he refused to talk about a unique Libyan identity, and when fighting for his life and calling upon Libyans to ensure his survival, they did not respond.

\section{Conclusions}

At present, (beginning of 2016) the Middle East is in the course of a historical shift. It is too presumptuous to predict when this process will be complete, if ever and how the region will reshape itself on "the day after". Having said that, the following conclusions may be drawn:

There is no solid liberal infrastructure for a unique nationality in any Arab state. There may be overt features such as a national anthem, flag or currency, but there is no substantial common denominator saves for Islam. Islam itself denies nationalism as an abstract idea that becomes tangible through nation states, and therefore, in this phase of Arab history, all current nation states are still looking for common values to help them build a national collective identity. Even in Egypt the public discussion over civil state or religious one is still going on.

The idea of pan-Arabism has failed. The Egyptian invasion of Yemen in 1962, the Iraqi incursion into

47 The Libyan Revolution, p. 203.

${ }^{48}$ St. John, 1983, p. 474.

49

expose

Gaddafi

corruption,

http://www.timesofmalta.com/articles/view/20110223/local/leaks-expose-gaddafi-corruption.351628.

50 Audio message broadcast on the pro-Gaddafi Syrian Al Rai TV on 20 September 2011: "I call on the Libyan people, men and women, to go out into the squares and the streets in all the cities in their millions. ... Go peacefully... be courageous, rise up, go to the streets, raise our green flags to the skies. ... Don't be afraid of anyone. You are the people. You have right on your side. You are the rightful people of this land". 
Kuwait in 1990, the civil wars in Yemen (1962-1970), Lebanon (1975) and the bloodshed in Syria, Libya and Yemen (2011-present) are all salient examples proving that group interests, and not necessarily national ones, prevail over Arab unity. Today, countries in the Middle East are facing an Islamic awakening. In some places like Syria, Iraq and Libya, the Islamic forces are challenging the incumbent regimes on a permanent basis. In other countries, "winds of Islamic change" are secretly blowing despite the fact that no upheaval has occurred yet. The effort to establish a new Caliphate is still a vision to be achieved, despite the new phenomenon of the Islamic State in Iraq and Syria.

As for Islam, the religious identity is still a dominant factor, but a new (or old) political power that will bring about the resolution of economic and social problems, or promote solutions to the population's needs, cannot be pointed to. In other words, Islam does not contribute to national feelings or to people's desire to see a more liberal society. Perhaps the option of starting from the beginning by creating a steady civil society is a better solution for these countries.

Arab leaders used to merge religion with nationalism when it served their interest. Even those who were adherent of secular ideas, like the Ba'ath party in Iraq and Syria, or Qadhafi in Libya, turned to Islam when they struggled to survive in the political arena. Jurgensmeyer defines it as a religious nationality, even if it was a fake in countries like Syria and Iraq. And they are not alone. Nonetheless, those leaders preferred to move away from religion, especially in heterogeneous societies where the flames of conflicts were too high to bridge the differences. The current struggle in Yemen between Sunni and Shiite groups enhances this argument. These could be referred to as instrumental nationalism, meaning anyone can pour any relevant content into the abstract term "nationalism" in order to survive, physically and politically, and promote his interests.

Finally, the absence of liberal nationalism in the Middle East increases uncertainty with regard to the stability of the states, particularly where societies are divided and the central regime is too weak. I am aware of the fact that some countries did not feel the turmoil, and each state requires different tools to analyze the implications of the Arab Spring; however, in a global world of websites and social networks, every dramatic event in one Arab state, in addition to the continued struggle between Sunnis and Shiites, will ultimately affect all Arab nation states in the region. So nation state exists, as does nationality (a flag, anthem, currency, and passport), but there is still a long way to go before a solid and stable value basis can be created to bind the people together.

\section{References}

Abduh, M. (1942-1943). Risalat al-Tawhid (The Theologyof Unity). Cairo: Ministry of Endowments. (In Arabic).

Ajami, F. (2009). The dream palace of the Arabs: A generation's odyssey. New York: Random House LLC.

Anderson, B. (2006). Imagined communities: Reflections on the origin and spread of nationalism. New York: Verso Books.

Al-Hayat. 2005. 3 May 2005. Beirut.

Al-Qaddisiyya.1990. 30 December 1990. Baghdad.

Al-Quds al-Arabi. 1998. 9 May 1998. London.

Barakat, H. (1993). The Arab world: Society, culture and state. California: University of California Press.

BBC Radio in Arabic, Interview with Syrian Minister of Religious Affairs, 7 September 2009.

Bengio, O. (2012). From Saddam to Sistani: Islamization in Iraq. Nationalism, secularization and religion in the Middle East. Tel Aviv: Tel Aviv University, Dayan Center.

Blanchrad, C. M., \& Zanotti, J. L. (2011). Lybia: Background and U.S. Relations. Congressional Research Service. Retrieved from http://fpc.state.gov/documents/organization/158525.pdf

Chapin Metz, H. (1988). A country study: Libya. Library of Congress. Retrieved February 27, 2015 from http://lcweb2.loc.gov/cgi-bin/query/r?frd/cstdy:@field(DOCID+ly0036) 
Gellner, E. (1983). Nations and nationalism: New perspectives on the past. Ithaca, NY: Cornell University Press.

Gera, G. (1983). Libya under Qadhafi. Tel Aviv: Tel Aviv University. (In Hebrew).

Greenfeld, L. (2004). Nationalism and the Mind. The Tenth Annual Gellner Lecture, London School of Economics, April $22,2004$.

Retrieved November 17, 2014, from http://w.tamilnation.co/selfdetermination/nation/liah.pdf

Hourani, A. (1970). Arabic thought in the liberal age 1798-1939. Oxford: Oxford University Press.

Hussein, S. (1979). Naz'ra fi al-Din wa al-Turath (A glance at religion and tradition). HawlaKitaba al-Ta'arikh (Around history writing). Baghdad: The National Library. (In Arabic).

Kader, H. E. (2014). SSNP Ideology. Retrieved November 21, 2014, from www.ssnp.org/new/ssnp/em/ssnp/htm

Kohn, H. (1946). The Idea of nationalism: A study in its origins and background. New York: Macmillan Company.

Maoz, M. (1974). Political and social change in a process of establishing political community. Tel Aviv: Reshafim. (In Hebrew).

Naqavi, A. M. (1998). Islam and nationalism. Alhoda UK.

Pipes, D. (1990). Greater Syria. Oxford: Oxford University Press.

Qadhafi, M. (1975). The green book (al-Kitab al-Ahdar). Tripoli: The World Center for Research in Tripoli. (In Arabic).

Qasem, A. (1899). Tahrir al-Mar'a (The liberation of women). Cairo: Al-Hindawi Institution for Education and Culture. (In Arabic).

Rabinovich, I. (1972). Syria under the Ba'ath Rule, 1963-1966. Jerusalem: Israel University Press.

Rida, M. R. (1931). Ta'rikh al-Austadhal-Imam al-Shaykh Muhammad Abduh (The history of Imam Sheikh Muhammad Abduh). Cairo: Dar Al-Fadilla. (In Arabic).

Sela, Y. (2014). Presidents, Prime Ministers and Parties in Syria from 1946 to 2000. The Mideast Forum. Retrieved November 28, 2014, from www.mideast.co.il

Silver, D. (2011). Gaddafi quotes: The dead Libya dictator in his own words-Top 20 quotes. Daily Mirror. Retrieved March 2, 2015, from http://www.mirror.co.uk/news/uk-news/gaddafi-quotes-the-dead-libya-dictator-275336

Smith, A. D. (2000). The nation in history: Historiographical debates about ethnicity and nationalism. UNPE.

St. John, R. B. (1983). The ideology of Muammar al-Qadhdhafi: Theory and practice. International Journal of Middle East Studies, 15(4), 471-490.

Tahtawi-al, R. (1912). Manahij al-Adabal-Misriyyafi Mabahijal-Adabal-Asriyya (The path of Egyptian minds in the joys of modern arts). Cairo: Al-Hindawi Institution for Education and Culture. (In Arabic).

Tamir, Y. (1995). The enigma of nationalism. World Politics, 3(47), 427.

Zisser, E. (2003). The face of Syria-Society, regime and state. Tel Aviv: Hakibutz Hameuhad. (In Hebrew). 